\title{
RAPD and SSR Based Genetic Diversity in Pistillate Parents of Castor (Ricinus communis L.) Germplasms
}

\author{
A. R. Aher*, M. S. Kamble, A. G. Bhoite and M. S. Mote \\ Agricultural Botany Division, RCSM College of Agriculture, Kolhapur 416004 \\ (University: Mahatma Phule Krishi Vidyapeeth, Rahuri, MAHARASHTRA), India \\ *Corresponding author
}

\section{A B S T R A C T}

\begin{abstract}
This study aimed to evaluate the genetic diversity and to characterize nine pistillate parents of castor (Ricinus communis L.) germplasms by RAPD and SSR markers. The availability of diverse germplasm of any crop is an important genetic resource to mine the genes that may assist in attaining yield as well as quality. The genomic DNA result of germplasms was amplified with forty nine oligonucleotide primers and twenty eight microsatellite primer pairs for RAPD and SSR assay, respectively. In RAPD analysis percent polymorphism ranged from $12.50 \%$ to $100 \%$ with an average percent polymorphism of 67.56. The PIC values varied from 0.55 to 0.93 with an average PIC value 0.844 . RAPDDendogram divided pistillate parents into two main clusters A and B, with Jaccard's similarity coefficient ranging from 0.67 to 0.85 . In SSR analysis, 28 primers generated 67 alleles with average of 2.39 alleles per primer. Simple sequence repeats analysis revealed $100 \%$ polymorphism with different fragments size; ranged from $138 \mathrm{bp}$ to $311 \mathrm{bp}$. The number of alleles in individual primer was ranged from two to four with an average of 0.43. The PIC values obtained in this study were substantially higher, which could be attributed due to high genotypic diversity of 9 castor genotypes. Clustering pattern of dendogram generated by pooled SSR data showed two major clusters A and B having similarity coefficient of 0.12 to 0.75 . Clustering of these pistillate lines was in accordance with their pedigree. Comparative account of RAPD and SSR markers showed that RAPD marker system was found to be superior to SSR markers. Even though SSR markers are coined to be superior to RAPD markers, identification of low number of alleles with SSR markers might be a possible reason that explains these contrasting results.
\end{abstract}

\section{Keywords}

RAPD, SSR, Castor, Ricinus communis L.,

\section{Article Info}

Accepted: 15 July 2020 Available Online: 10 August 2020

\section{Introduction}

Castor (Ricinus communis L., $2 \mathrm{n}=2 \mathrm{x}=20$ ) is an industrially important non-edible oilseed crop widely cultivated in the arid and semiarid regions of the world (Govaerts et al.,
2000). The genus Ricinus is monotypic and $R$. communis is the only species with the most polymorphic forms known (Weiss, 2000). All the varieties investigated cytologically are diploids and it is presumed to be a secondarybalanced polyploid with a basic number of 
$x=5$ (Singh, 1976). Many of the morphological differences might be due to genic differences, cryptic inversions, duplications, etc., rather than to changes in the whole chromosome complement (Perry, 1943).

It has an ability to grow under low-rainfall and low-fertility conditions, and hence is most suitable for dry land farming. The seed of castor contains more than $45 \%$ oil, and this oil is rich $(80-90 \%)$ in an unusual hydroxyl fatty acid, ricinoleic acid. Due to its unique chemical and physical properties, the oil from castor seed is used as raw material for numerous and varied industrial applications, such as: manufacturing of polymers, coatings, lubricants for aircrafts, cosmetics etc., and for the production of biodiesel (Jeong and Park, 2009).

More than $95 \%$ of the world's castor production is concentrated in limited parts of India, Chinaand Brazil (Sailaja et al., 2008), and because of the ever increasing worldwide demand of castor for industrial usage, there is a pressing need to increase the hectare and productivity of castor. Being the largest producer, India is also largest exporter of castor seed oil and exports $80 \%$ of its total castor oil to China, which is the world's largest importer of castor oil followed by US, Japan, Thailand and other European countries. India's export of castor oil and derivatives are estimated to be over Rs.4000 cores (US \$ 800 million) per annum, and the whole world is highly dependent on India for the supply of this oil, which is used in production of some vital chemicals (Anon., 2012a).

Castor is a sexually polymorphic species with different sex forms viz., monoecious, pistillate, hermaphrodite and pistillate with interspersed staminate flowers (ISF). The most natural occurrence of annual and perennial castor is monoecious form. The spike has basal $1 / 3$ to $1 / 2$ male flowers, while the top portion has female flowers. In between these few whorls have both male and female flowers in an interspersed fashion. Pistillate $(\mathrm{P})$ spike occurs as a rare recessive mutant with the spike having female flowers throughout the spike. A variant of pistillate form with male flowers interspersed throughout the female flowers on the spike is termed as interspersed staminate flower (ISF). Sex revertant is basically a female form that turns to monoecious form or reverts at later stage (Ramachandram and Rangarao, 1988 and Lavanya, 2002). Dominant female mutants are spontaneous and genetically unstable. Such female plants produce female racemes at first, but later revert to production of monoecious racemes having both male and female flowers. Such females are used in hybrid seed production programme and could be maintained easily. Pistillate condition is produced by blocking the development of androecium in the male flower, so that the inflorescence has only pistillate flowers. Conventional diversity analysis methods in the field are time consuming, laborious, resource intensive and drastically affected by environmental factors, therefore, a technique that is rapid and not affected by environment is needed for assessment of genetic diversity, and selection of parental lines for use in hybrid development programmes. Genetic diversity assessment prior to developing hybrids can aid in better exploitation of heterosis. Assessment of genetic variation using molecular markers appears to be an attractive alternative to the conventional diversity analysis, and can also aid in management and conservation of biodiversity.

Random Amplified Polymorphic DNA (RAPD) and Simple Sequence Repeats (SSR) markers on the other hand, require only small amounts of DNA sample without involving radioactive labels and are simpler as well as faster. RAPD has proven to be quite efficient 
in detecting genetic variations, and used for diversity assessment and for identifying germplasm in a number of plant species (Welsh and McClelland, 1990; Gwanama et al., 2000; Kapteyn and Simon, 2002). SSR has been shown to provide a powerful, rapid, simple, reproducible and inexpensive means to assess genetic diversity and identify differences between closely related cultivars in many species (Bajayet al., 2011). Limited studies have been carried out on the genetic diversity and phylogenetics of castor using molecular markers. The objective of the present study was to investigate and characterize the genetic diversity present in the pistillate genotypes of castor using RAPD and SSR markers, with an ultimate aim of accurate assessment of genetic diversity and its application in development of hybrids pistillate lines with higher production potential. The identified polymorphic markers could also be exploited for genetic improvement of castor through breeding and Marker Assisted Selection (MAS), as well as, in future germplasm conservation strategies. Successful breeding programs depend on the complete knowledge and understanding of the genetic diversity within and among genetic resources of the available germplasms. This will enable plant breeders to choose parental sources that generate diverse populations for selection (Esmail et al., 2008).

\section{Materials and Methods}

Morphologically diverse nine pistillate line of Ricinus communis L. viz. ANDCP-08-01, ANDCP-06-07, ACP-1-06-07, SKP-84, VP-1, DPC-9, JP-65, ANDCP-06-07-1 and ANDCP-06-07-2developed at the AAU, Anand; GAU, S. K. Nagar; Vijapur, Gujarat, DOR, Hyderabad and JAU, Junagadh were investigated in this study. Seeds were initially collected from the Regional Research Station, Anand Agricultural University, Anand during Late Kharif - Rabi2011-12.

\section{DNA isolation}

Leaves were harvested and total genomic DNA was extracted by using a modified CTAB method (Doyle and Doyle 1987). DNA concentration was quantified through spectrophotometer Nanodrop N.D.1000 (Software V.3.3.0, Thermo Scientific, U.S.A.). The concentration of DNA and absorbance at $260 \mathrm{~nm}$ and $280 \mathrm{~nm}$ were measured. The A 260/280 readings for DNA samples were 1.6-1.8.

\section{PCR amplification and primer survey}

The PCR reaction mixture for $25 \mu \mathrm{L}$ contained template DNA (25 ng) $2 \mu \mathrm{L}$, deionized distilled water $18.8 \mu \mathrm{L}$, Taq buffer A $10 \times$ (Tris with $15 \mathrm{mM} \mathrm{MgCl} 2$ ) $2.5 \mu \mathrm{L}$, primer $(10 \mu \mathrm{M}) 1.0 \mu \mathrm{L}$, dNTPs $(2.5 \mathrm{mM}) 0.5 \mu \mathrm{L}$ and Taq DNA polymerase $(5 \mathrm{U} \mu \mathrm{L}-1) 0.2 \mu \mathrm{L}$. PCR amplification was done in an oil-free thermal cycler (Biometra UNOII, Germany) for 46 cycles after initial denature at $94^{\circ} \mathrm{C}$ for $5 \mathrm{~min}$, denature at $94^{\circ} \mathrm{C}$ for $1 \mathrm{~min}$, annealing at $34-36^{\circ} \mathrm{C}$ for $30 \mathrm{~s}$, extension at $72^{\circ} \mathrm{C}$ for 3 min and final extension at $72^{\circ} \mathrm{C}$ for $5 \mathrm{~min}$. In the present study, 49 oligonucleotide primers and 28 microsatellite primer pairs were used for RAPD and SSR assay, respectively (Table 1 and 2).

\section{Gel electrophoresis}

The amplified products were separated electrophoretically on $1 \%$ agarose gel. The gel was prepared using $1.0 \mathrm{~g}$ agarose powder containing ethidium bromide (10 mg mL-1) 8 $\mu \mathrm{L}$ and $100 \mathrm{~mL} 1 \times \mathrm{TAE}$ buffer. Agarose gel electrophoresis was conducted in $1 \times \mathrm{TAE}$ buffer at $50 \mathrm{~V}$ and $100 \mathrm{~mA}$ for $1.5 \mathrm{~h}$. DNA ladder $(1 \mathrm{~kb})$ was electrophoresed alongside the RAPD and SSR reactions as marker. DNA bands were observed on UV-transilluminator and photographed by a gel documentation system. 


\section{Scoring and data analysis}

The PCR products were analyzed after gel electrophoresis. The photographs were critically discussed on the basis of presence (1) or absence (0), size of bands and overall polymorphism of bands. These were carried out for further investigation. The scores obtained using all primers in the RAPD analysis were then pooled for constructing a single data matrix. This was used for estimating polymorphic loci, gene diversity, genetic distance (D) and constructing a UPGMA (Unweighted Pair Group Method of Arithmetic Means) method by SAHN clustering function of NTSYSpc. Relationships among the castor genotypes were expressed in the form of dendrograms and genetic similarity matrix.

\section{Results and Discussion}

The nine pistillate parents of castor selected for the present study represented a broad spectrum of variation for several phenotypic traits. DNA from the all pistillate parents were studied with 49 oligonucleotide primers and 28 microsatellite primer pairs for RAPD and SSR assay, respectively.

\section{Polymorphism as detected by RAPD analysis (Table 1)}

A total of 180 RAPD primers were screened; out of which, 49 primers with good number of polymorphism were selected. The 49 primers produced 440 DNA fragments. The number of amplified fragments ranged from three (OPM11) to sixteen (OPA-13), with the amplicons size ranging from $112 \mathrm{bp}$ (OPE-16) to $3174 \mathrm{bp}$ (OPB-04). Among 440 bands amplified, 292 were polymorphic with an average of 5.8 polymorphic bands per primers. Total 55 genotype specific bands were obtained from 39 primers. Percent polymorphism ranged from $12.50 \%$ (OPF-05) to $100 \%$ (OPB-04,
OPC-04, OPD-02, OPE-02, OPE-14, OPE-15, OPE-16, OPF-03 and OPM-14) with an average percent polymorphism of 67.56 . The PIC values varied from 0.55 (OPM-11) to 0.93 (OPA-13) with an average PIC value 0.844 . RAPD-Dendogram divided pistillate parents into two main clusters $\mathrm{A}$ and $\mathrm{B}$, with Jaccard's similarity coefficient ranging from 0.67 to 0.85 .

\section{Dendogram clustering for RAPD marker}

In figure 1, cluster $\mathrm{A}$ consisted of six genotypes, while cluster $\mathrm{B}$ consisted of three genotypes. Cluster $\mathrm{A}$ was again divided in to two sub clusters A1 and A2. Both these sub clusters each comprised three pistillate parents, A1 comprised parents ANDCP-0607-1, ANDCP-06-07-2 and JP-65; whereas, A2 had DPC-9, VP-1 and SKP-84 parents. Cluster B comprised remaining three pistillate lines ANDCP-08-01, ANDCP-06-07 and ACP-1-06-07. The highest similarity index value of 0.85 was found between parents ANDCP-06-07-1 and ANDCP-06-07-2, while the least similarity index value of 0.58 was found between ACP-1-06-07 and JP-65. Clustering of these pistillate lines was in accordance with their pedigree.

Polymorphism as detected by SSR analysis (Table 2)

In SSR analysis, 28 primers generated 67 alleles with average of 2.39 alleles per primer. Simple sequence repeats analysis revealed $100 \%$ polymorphism among the different castor genotypes studied. The SSR primers tested in present investigation produced fragments of different size; ranged from $138 \mathrm{bp}$ to $311 \mathrm{bp}$. The number of alleles in individual primer was ranged from two to four with an average of 0.43 . The PIC value ranged from 0.20 (GB-RC-046, GB-RC-098, GB-RC-133, GB-RC-135 and GB-RC-174) to 0.69 (GB-RC-002) with an average of 0.43 . 
Table.1 Compilation of RAPD analysis in 09 pistillate lines of castor

\begin{tabular}{|c|c|c|c|c|c|c|c|}
\hline $\begin{array}{l}\text { Sr. } \\
\text { No. }\end{array}$ & $\begin{array}{c}\text { Primer } \\
\text { name }\end{array}$ & $\begin{array}{l}\text { Range of amplified } \\
\text { fragments (bp) }\end{array}$ & $\begin{array}{l}\text { Total number } \\
\text { of bands }\end{array}$ & $\begin{array}{l}\text { Number of poly- } \\
\text { morphic bands }\end{array}$ & $\begin{array}{l}\text { Number of mono- } \\
\text { morphic bands }\end{array}$ & $\begin{array}{l}\text { Polymor- } \\
\text { phism (\%) }\end{array}$ & $\begin{array}{c}\text { PIC } \\
\text { Value }\end{array}$ \\
\hline 1 & OPA-02 & $256-3048$ & 11 & 7 & 4 & 63.64 & 0.905 \\
\hline 2 & OPA-03 & $345-1439$ & 7 & 6 & 1 & 85.71 & 0.839 \\
\hline 3 & OPA-04 & $334-2583$ & 10 & 5 & 5 & 50.00 & 0.877 \\
\hline 4 & OPA-13 & $234-2014$ & 16 & 5 & 11 & 31.25 & 0.931 \\
\hline 5 & OPA-17 & $218-1324$ & 6 & 5 & 1 & 83.33 & 0.839 \\
\hline 6 & OPA-18 & $287-2023$ & 7 & 5 & 2 & 71.43 & 0.804 \\
\hline 7 & OPB-03 & $313-2453$ & 7 & 5 & 2 & 71.43 & 0.770 \\
\hline 8 & OPB-04 & $176-3174$ & 8 & 8 & 0 & 100.00 & 0.860 \\
\hline 9 & OPB-06 & $333-920$ & 5 & 4 & 1 & 80.00 & 0.763 \\
\hline 10 & OPB-20 & $294-2521$ & 13 & 11 & 2 & 84.62 & 0.855 \\
\hline 11 & OPC-01 & $164-2447$ & 12 & 8 & 4 & 66.67 & 0.887 \\
\hline 12 & OPC-02 & 298-1996 & 11 & 5 & 6 & 45.45 & 0.899 \\
\hline 13 & OPC-04 & $489-2017$ & 7 & 7 & 0 & 100.00 & 0.793 \\
\hline 14 & OPC-05 & $393-2259$ & 10 & 7 & 3 & 70.00 & 0.857 \\
\hline 15 & OPC-10 & $346-1595$ & 6 & 4 & 2 & 66.67 & 0.807 \\
\hline 16 & OPC-11 & $482-2541$ & 6 & 3 & 3 & 50.00 & 0.752 \\
\hline 17 & OPC-14 & $462-1545$ & 5 & 3 & 2 & 60.00 & 0.781 \\
\hline 18 & OPC-15 & 189-1959 & 8 & 4 & 4 & 50.00 & 0.865 \\
\hline 19 & OPD-02 & $219-862$ & 8 & 8 & 0 & 100.00 & 0.834 \\
\hline 20 & OPD-03 & $215-1660$ & 15 & 12 & 3 & 80.00 & 0.915 \\
\hline 21 & OPD-08 & $208-2015$ & 13 & 5 & 8 & 38.46 & 0.914 \\
\hline 22 & OPD-15 & $256-2300$ & 7 & 5 & 2 & 71.43 & 0.838 \\
\hline 23 & OPD-18 & $260-834$ & 7 & 4 & 3 & 57.14 & 0.824 \\
\hline 24 & OPD-20 & $174-2435$ & 10 & 9 & 1 & 90.00 & 0.846 \\
\hline 25 & OPE-01 & $225-2258$ & 12 & 6 & 6 & 50.00 & 0.899 \\
\hline 26 & OPE-02 & $410-2528$ & 13 & 13 & 0 & 100.00 & 0.888 \\
\hline 27 & OPE-03 & $205-1120$ & 7 & 3 & 4 & 42.86 & 0.851 \\
\hline 28 & OPE-04 & $265-888$ & 7 & 1 & 6 & 14.29 & 0.855 \\
\hline 29 & OPE-07 & $167-1149$ & 9 & 8 & 1 & 88.89 & 0.879 \\
\hline 30 & OPE-09 & 213-1844 & 9 & 2 & 7 & 22.22 & 0.883 \\
\hline 31 & OPE-14 & $133-924$ & 5 & 5 & 0 & 100.00 & 0.713 \\
\hline 32 & OPE-15 & $118-1246$ & 11 & 11 & 0 & 100.00 & 0.905 \\
\hline 33 & OPE-16 & $112-1993$ & 10 & 10 & 0 & 100.00 & 0.858 \\
\hline 34 & OPE-18 & $188-1465$ & 12 & 6 & 6 & 50.00 & 0.913 \\
\hline 35 & OPF-01 & $339-2587$ & 6 & 0 & 6 & 0.00 & - \\
\hline 36 & OPF-03 & $548-2087$ & 6 & 6 & 0 & 100.00 & 0.816 \\
\hline 37 & OPF-05 & 228-1947 & 8 & 1 & 7 & 12.50 & 0.875 \\
\hline 38 & OPF-06 & $311-2044$ & 9 & 5 & 4 & 55.56 & 0.830 \\
\hline 39 & OPF-10 & $232-1288$ & 7 & 6 & 1 & 85.71 & 0.839 \\
\hline 40 & OPF-13 & 254-1906 & 13 & 9 & 4 & 69.23 & 0.911 \\
\hline 41 & OPF-14 & $146-2063$ & 12 & 7 & 5 & 58.33 & 0.892 \\
\hline 42 & OPL-02 & $439-2496$ & 7 & 4 & 3 & 57.14 & 0.822 \\
\hline 43 & OPL-10 & $275-1413$ & 8 & 7 & 1 & 87.50 & 0.875 \\
\hline 44 & OPL-13 & $653-2378$ & 7 & 6 & 1 & 85.71 & 0.855 \\
\hline 45 & OPL-16 & $287-2051$ & 10 & 8 & 2 & 80.00 & 0.888 \\
\hline 46 & OPM-01 & $263-2061$ & 13 & 5 & 8 & 38.46 & 0.914 \\
\hline 47 & OPM-10 & $416-2010$ & 10 & 6 & 4 & 60.00 & 0.857 \\
\hline 48 & OPM-11 & $749-858$ & 3 & 2 & 1 & 66.67 & 0.549 \\
\hline 49 & OPM-14 & $289-1083$ & 4 & 4 & 0 & 100.00 & 0.730 \\
\hline 50 & OPY-14 & $541-1906$ & 7 & 6 & 1 & 85.71 & 0.802 \\
\hline \multicolumn{2}{|r|}{ Total } & - & 440 & 292 & 148 & 3378.01 & 41.354 \\
\hline \multicolumn{2}{|c|}{ Average } & - & 8.8 & 5.8 & 2.96 & 67.56 & 0.844 \\
\hline
\end{tabular}


Table.2 Compilation of SSR analysis in in 09 pistillate lines of castor

\begin{tabular}{|c|c|c|c|c|c|c|}
\hline Sr. No. & $\begin{array}{c}\text { SSR } \\
\text { markers }\end{array}$ & $\begin{array}{c}\begin{array}{c}\text { Range of } \\
\text { amplified } \\
\text { fragments (bp) }\end{array}\end{array}$ & $\begin{array}{l}\text { No. of } \\
\text { alleles }\end{array}$ & $\begin{array}{l}\text { No. of rare } \\
\text { alleles }\end{array}$ & $\begin{array}{c}\text { PIC } \\
\text { value }\end{array}$ & Cultivar specific band \\
\hline 1 & GB-RC-001 & $246-249$ & 2 & - & 0.44 & - \\
\hline 2 & GB-RC-002 & $217-246$ & 4 & 1 & 0.69 & ANDCP-06-07 \\
\hline 3 & GB-RC-004 & $300-311$ & 3 & 1 & 0.49 & ANDCP-08-01 \\
\hline 4 & GB-RC-019 & $233-252$ & 2 & - & 0.35 & - \\
\hline 5 & GB-RC-021 & $177-190$ & 2 & - & 0.44 & - \\
\hline 6 & GB-RC-025 & $159-174$ & 2 & - & 0.44 & - \\
\hline 7 & GB-RC-031 & $252-266$ & 2 & - & 0.44 & - \\
\hline 8 & GB-RC-038 & $138-148$ & 2 & - & 0.49 & - \\
\hline 9 & GB-RC-046 & $273-284$ & 2 & 1 & 0.20 & ANDCP-08-01 \\
\hline 10 & GB-RC-059 & $256-281$ & 2 & - & 0.49 & - \\
\hline 11 & GB-RC-062 & $218-254$ & 3 & - & 0.64 & - \\
\hline 12 & GB-RC-070 & $233-263$ & 2 & - & 0.44 & - \\
\hline 13 & GB-RC-080 & $161-185$ & 3 & - & 0.67 & - \\
\hline 14 & GB-RC-088 & $243-282$ & 3 & - & 0.64 & - \\
\hline 15 & GB-RC-096 & $158-171$ & 4 & 2 & 0.67 & ANDCP-08-01, SKP-84 \\
\hline 16 & GB-RC-098 & $273-288$ & 2 & 1 & 0.20 & ANDCP-06-07-2 \\
\hline 17 & GB-RC-105 & $174-206$ & 3 & 2 & 0.37 & $\begin{array}{l}\text { ANDCP-08-01, ANDCP- } \\
06-07-2\end{array}$ \\
\hline 18 & GB-RC-107 & $176-183$ & 2 & - & 0.49 & - \\
\hline 19 & GB-RC-110 & $148-176$ & 3 & - & 0.59 & - \\
\hline 20 & GB-RC-133 & $252-289$ & 2 & 1 & 0.20 & ANDCP-08-01 \\
\hline 21 & GB-RC-135 & $283-294$ & 2 & 1 & 0.20 & DPC-9 \\
\hline 22 & GB-RC-169 & $151-177$ & 2 & - & 0.35 & - \\
\hline 23 & GB-RC-171 & $243-261$ & 2 & - & 0.35 & - \\
\hline 24 & GB-RC-174 & $211-232$ & 2 & 1 & 0.20 & ANDCP-08-01 \\
\hline 25 & GB-RC-177 & $165-176$ & 2 & - & 0.49 & - \\
\hline 26 & GB-RC-217 & $171-180$ & 2 & - & 0.35 & - \\
\hline 27 & GB-RC-225 & $263-284$ & 3 & 1 & 0.49 & ACP-1-06-07 \\
\hline \multirow[t]{3}{*}{28} & GB-RC-232 & $262-273$ & 2 & - & 0.35 & - \\
\hline & Total & - & 67 & 12 & 12.16 & \\
\hline & Average & - & 2.39 & 0.43 & 0.43 & \\
\hline
\end{tabular}


Table.3 Comparative account of RAPD and SSR markers

\begin{tabular}{|r|l|c|c|}
\hline Sr. No. & Particulars & RAPD & SSR \\
\hline $\mathbf{1 .}$ & No. of polymorphic band & 292 & 67 \\
\hline $\mathbf{2 .}$ & Average polymorphism & $67.56 \%$ & $100.00 \%$ \\
\hline $\mathbf{3 .}$ & Maximum band size & $3174 \mathrm{bp}$ & $311 \mathrm{bp}$ \\
\hline $\mathbf{4 .}$ & Minimum band size & $112 \mathrm{bp}$ & $138 \mathrm{bp}$ \\
\hline $\mathbf{5 .}$ & Polymorphism information content (PIC) & 0.84 & 0.43 \\
\hline $\mathbf{6 .}$ & Similarity coefficient value & & \\
\hline & a. Lowest & 0.58 & 0.12 \\
\hline & b. Highest & 0.85 & 0.75 \\
\hline & c. Average & 0.69 & 0.38 \\
\hline $\mathbf{7 .}$ & Cophenotic correlation & 0.76 & 0.99 \\
\hline $\mathbf{8 .}$ & Marker index & 5.84 & 1.03 \\
\hline
\end{tabular}

Figure.1 Dendogram showing clustering of 9 castor pistillate parents constructed using UPGMA based on Jaccard's coefficient obtained from pooled RAPD analysis

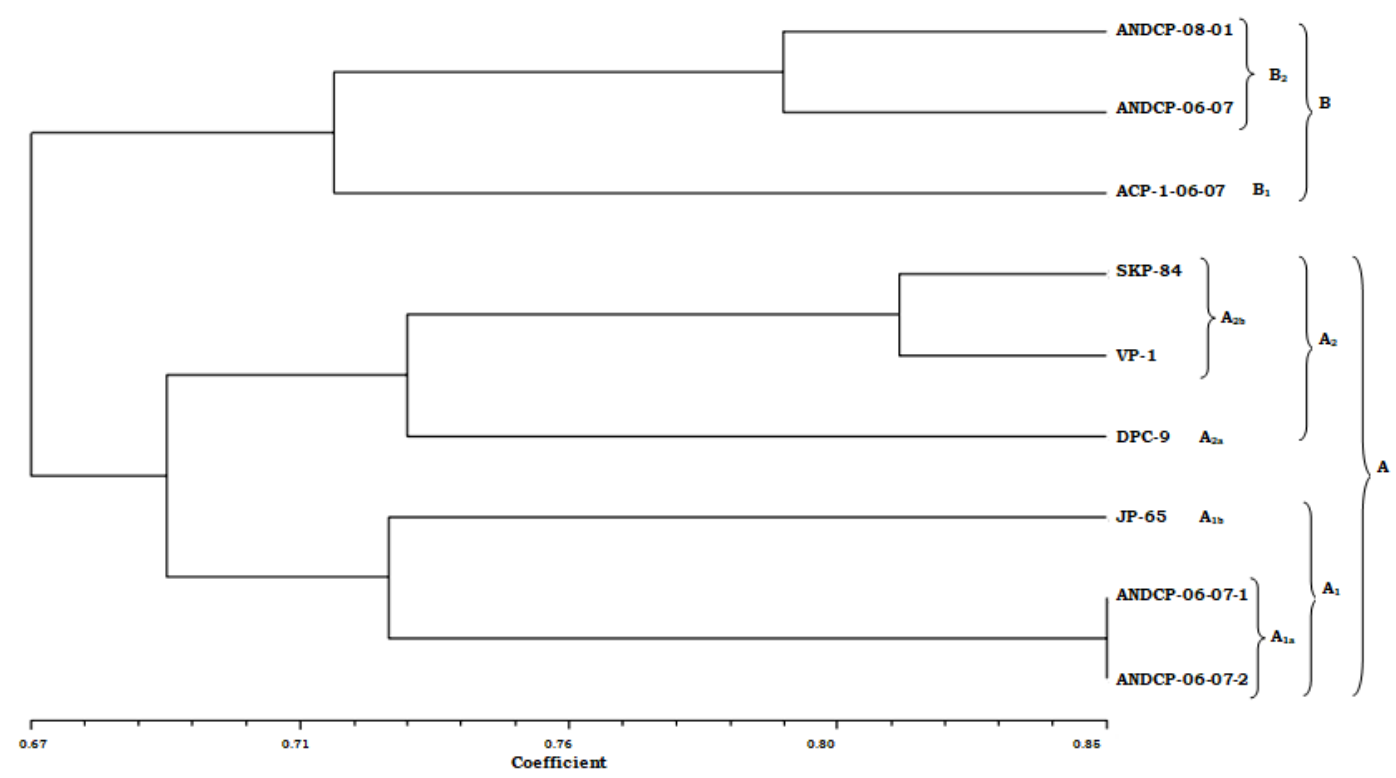


Figure.2 Dendogram showing clustering of 9 castor pistillate genotypes constructed using UPGMA based on Jaccard's coefficient obtained from pooled SSR analysis

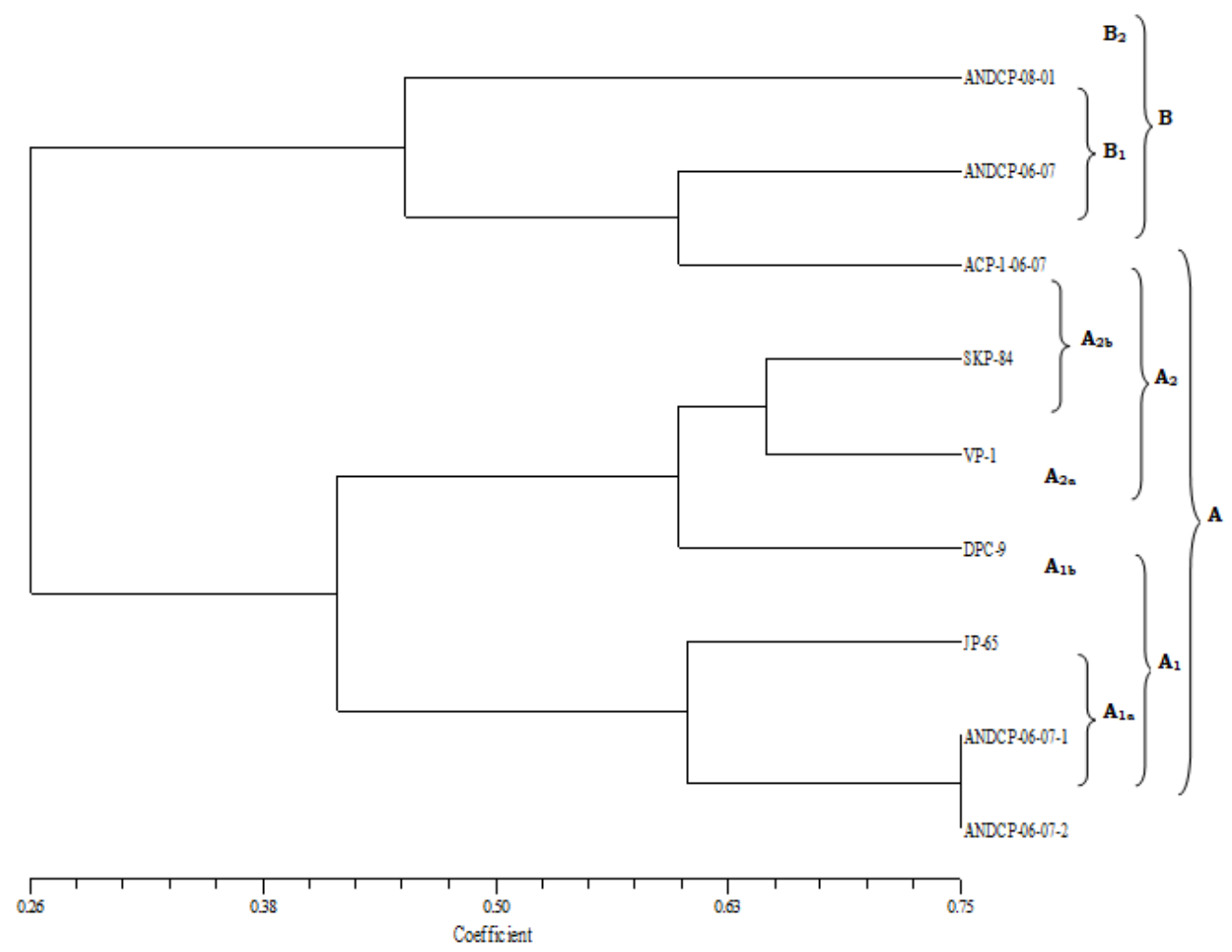

The PIC values obtained in this study were substantially higher than the earlier reports of Allan et al., 2008 [0.078 to $0.647($ mean $=$ 0.403)], Bajay et al., 2009 [0.078 to 0.647(mean=0.403)] and Seo et al., (2011) $[0.03$ to $0.47($ mean $=0.26)]$. Therefore, the higher PIC value in this study could be attributed due to high genotypic diversity of 9 castor pistillate genotypes. The PIC values (PIC $>0.5)$ considered as more informative for diversity analysis.

\section{Dendogram clustering for SSR marker}

In figure 2, Clustering pattern of dendogram generated by pooled SSR data showed two major clusters $\mathrm{A}$ and $\mathrm{B}$ having similarity coefficient of 0.12 to 0.75 . Cluster A was divided into two sub clusters A1 and A2. Sub- cluster A1 divided into group A1a and A1b. Genotypes ANDCP-06-07-1 and ANDCP-0607-2 were in group A1a and JP-65 in group A1b. Sub-cluster A2 divided into group A2a and A2b. Genotypes SKP-84 and VP-1 were in group A2a and DPC-9 in group A2b. Three genotypes were grouped in Cluster B. Genotypes ANDCP-06-07 and ACP-1-06-07 was in group B1 and ANDCP-08-01 in group B2.

\section{Comparative account of RAPD and SSR markers (Table 3)}

RAPD marker system was found to be superior to SSR markers. Even though SSR markers are coined to be superior to RAPD markers, identification of low number of alleles with SSR markers might be a possible 
reason that explains these contrasting results. The number of polymorphic bands amplified by RAPD primers (292) was more compared to SSR markers (67). This could be due to fact that RAPD markers are whole genome based markers; whereas, SSR markers are locus specific. The SSR markers used in the present study detected low allelic variation at their corresponding loci, which would be observed from low PIC value of 0.43 , which was high for RAPD marker (0.84). In case of determining genetic similarity, SSR markers detected the least similarity value of 0.12 compared to 0.58 by RAPD markers. This explained the discriminative power of SSR markers. The cophenotic correlation analysis revealed that the dendogram constructed based on the SSR molecular data was more conserved than RAPD, since cophenotic correlation value of SSR marker $(r=0.99)$ was higher than RAPD marker ( $r=0.76)$. A high value of marker index (5.84) was obtained for RAPD compared to value of 1.03 for SSR markers. Such results would be obtained for SSR markers, because the number of alleles, PIC value of SSR markers may be influenced by the sample size. Since number of alleles amplified would increase with the increase in sample size.

\section{References}

Allan, G., Williams, A., Rabinowicz, P. D., Chan, A. P., Ravel, J. and Keim, P. (2008).Worldwide genotyping of castor bean germplasm (Ricinus communis L.) using AFLPs and SSRs. Genet. Resour. Crop. Evol., 55: 365-378.

Anonymous (2012a). Special report on castor seed. ITI Investor services Ltd. Kalpataru Heritage, $4^{\text {th }}$ Floor, 127 M. G. Road, Fort, Mumbai - 01 (http://www.itiisl.com/Admin/Research/ 602.pdf).

Bajay, M. M., Pinheiro, J. B., Batista, C. E. A., Nobrega, M. B. M. and Zucchi, M.
I. (2009). Development and characterization of microsatellite markers for castor (Ricinus communis L.), an important oleaginous species for biodiesel production. Conservation Genet Resour., 1: 237-239.

Bajay, M. M., Zucchi, M. I., Kiihl, T. A. M., Batista, C. E. A., Monteiro, M. and Pinheiro, J. B. (2011). Development of a novel set of microsatellite markers for castor bean (Ricinus communis). American Journal of Botany. Pp. 87-89.

Doyle, J. J. and Doyle, J. L. (1990). Isolation of plant DNA from fresh tissue. Focus; 12: 13-15.

Esmail, R. M., Zhang, J. F. and Abdel-Hamid, A. M. (2008). Genetic diversity in elite cotton germplasm lines using field performance and RAPD markers. World J. Agric. Sci. 4: 369-375.

Govaerts, R., Frodin, D. G. and RadcliffeSmith, A. (2000). World Check list and Bibliography of Euphorbiaceae (with Pandaceae). Redwood Books Limited, Trowbridge, Wiltshire.

Gwanama, C., Labuschagne, M. T. and Botha, A. M. (2000).Analysis of genetic variation in Cucurbitamoschata by random amplified polymorphic DNA (RAPD) markers.Euphytica, 113: 1924.

Jeong, G. T. and Park, D. H. (2009). Optimization of biodiesel production from castor oil using response surface methodology. Appl. Biochem. Biotechnol., 156: 431-441.

Kapteyn, J. and Simon, J. E. (2002). The use of RAPDs for assessment of identity, diversity and quality of Echinacea. In: Janick, J., Whipkey, A. (Eds.), Trends in New Crops and New Uses. ASHS Press, Alexandria, VA, pp. 509-513.

Lavanya, C. (2002). Sensitivity of sex expression and sex variation in castor (Ricinus communis L.) to environmental changes. Indian J. Genet., 62(3): 232- 
237.

Perry, B. A. (1943). Chromosome number and phylogenetic relationships in the Euphorbiaceae. Amer J. Bot., 30: 527 543.

Ramachandram, M. and Rangarao, V. (1988). Seed production in castor. In: Technology bulletin. Directorate of Oilseeds Research, Hyderabad. PP. 4245.

Sailaja, M., Tarakeswari, M. and Sujatha, M., (2008). Stable genetic transformation of castor (Ricinus communis L.) via particle gun-mediated gene transfer using embryo axes from mature seeds. Plant Cell Rep., 27: 1509-1519.

Seo, K. I., Lee, G. A., Ma, K. H., Hyun, D.
Y., Park, Y. J., Jung, J. W., Lee, S. Y., Gwag, J. G., Kim, C.K. and Lee, M. C. (2011). Isolation and characterization of 28 polymorphic SSR loci from castor bean (Ricinus communis L.). J. Crop Sci. Biotech., 14 (2): 97-103.

Singh, D. (1976). Castor - Ricinus communis (Euphorbiaceae). In: Simmonds N. W., editor. Evolution of Crop Plants. London: Longman; p. 84-86.

Weiss, E. A. (2000). Castor: Oilseed Crops. Oxford, U.K., Blackwell Science; p. 1352.

Welsh, J. and McClelland, M. (1990). Fingerprinting genomes using PCR with arbitrary primers. Nucleic Acids Res., 18: 7213-7218.

\section{How to cite this article:}

Aher, A. R., M. S. Kamble, A. G. Bhoite and Mote, M. S. 2020. RAPD and SSR Based Genetic Diversity in Pistillate Parents of Castor (Ricinus communis L.) Germplasms. Int.J.Curr.Microbiol.App.Sci. 9(08): 1333-1342. doi: https://doi.org/10.20546/ijcmas.2020.908.151 